\title{
Secondary metabolites from Bacillus amyloliquefaciens isolated from soil can kill Burkholderia pseudomallei
}

\author{
Patcharaporn Boottanun ${ }^{1,2}$, Chotima Potisap ${ }^{1,2}$, Julian G. Hurdle ${ }^{3}$ and Rasana W. Sermswan ${ }^{1,2^{*}}$ (D)
}

\begin{abstract}
Bacillus species are Gram-positive bacteria found in abundance in nature and their secondary metabolites were found to possess various potential activities, notably antimicrobial. In this study, Bacillus amyloliquefaciens N2-4 and N3-8 were isolated from soil and their metabolites could kill Burkholderia pseudomallei, a Gram-negative pathogenic bacterium also found in soil in its endemic areas. Moreover, the metabolites were able to kill drug resistant isolates of $B$. pseudomallei and also inhibit other pathogenic bacteria such as Staphylococcus aureus, Escherichia coli and Acinetobacter baumannii but not the non-pathogenic Burkholderia thailandensis, which is closely related to B. pseudomallei. Since the antimicrobial activity of N3-8 was not partially decreased or abolished when treated with proteolytic enzymes or autoclaved, but N2-4 was, these two strains should have produced different compounds. The N3-8 metabolites with antimicrobial activity consisted of both protein and non-protein compounds. The inhibition spectrum of the precipitated proteins compared to the culture supernatant indicated a possible synergistic effect of the non-protein and peptide compounds of N3-8 isolates against other pathogens. When either N2-4 or N3-8 isolates was co-cultured with B. pseudomallei the numbers of the bacteria decreased by $5 \log _{10}$ within $72 \mathrm{~h}$. Further purification and characterization of the metabolites is required for future use of the bacteria or their metabolites as biological controls of B. pseudomallei in the environment or for development as new drugs for problematic pathogenic bacteria.
\end{abstract}

Keywords: Bio-control, Antimicrobial peptides, Pathogenic bacteria, Secondary metabolites

\section{Introduction}

Bacillus spp. are Gram-positive bacteria found diversely in nature especially in soil. In unsuitable conditions such as high temperature, radiation and harsh chemical reagents, they can form endospores for survival (Errington 2003). Besides spore forming, Bacillus spp. are also able to produce secondary metabolite products (Sansinenea and Ortiz 2011), which is an additional function to compete against other organisms. Bioactive compounds from Bacillus subtilis, bacteriocin-like substances, were reported to inhibit several clinical bacteria such as Listeria monocytogenes, Staphylococcus aureus, Bacillus cereus, Salmonella typhi (Xie et al. 2009) and also a

\footnotetext{
*Correspondence: rasana@kku.ac.th

1 Department of Biochemistry, Faculty of Medicine, Khon Kaen University, 123 Mitraparb Rd, Muang District, Khon Kaen Province 40002, Thailand Full list of author information is available at the end of the article
}

substance from Bacillus licheniformis could inhibit food spoilage bacteria (Guo et al. 2012). Moreover, the culture supernatant from Bacillus spp. isolated from soil named KW and SA was reported to contain $\mathrm{N}$-acyl homoserine lactone that significantly decreased biofilm formation of Burkholderia pseudomallei (Ramli et al. 2012). In addition, the Bacillus strain TKS1-1 in endospore form, was used to reduce the incidence of citrus bacterial canker (Huang et al. 2012). Some Bacillus spp. can produce several types of active compounds such as $B$. amyloliquefaciens FZB42 that has $8.5 \%$ of the genome dedicated for the synthesis of secondary metabolites (Chen et al. 2007). It can produce lipopeptides; surfactin, fengycin, bacillomycin D, polyketide (difficidin) and dipeptide bacilysin that can suppress growth of Erwinia amylovora (Chen et al. 2009). 
Melioidosis is one of infectious diseases that pose a significant public health problem in Southeast Asia and North Australia. The causative agent is B. pseudomal$l e i$, a Gram-negative bacteria which can be found in soil and water in endemic areas (Cheng and Currie 2005). Melioidosis is the third most cause of death among the infectious diseases in northeast Thailand and is responsible for $20 \%$ of community acquired septicemias with a $40 \%$ mortality rate (Wiersinga et al. 2012). The bacterium is intrinsically resistant to several antibiotics and acquired resistant to ceftazidime the drug of choice after lost a penicillin-binding protein 3 gene (Chantratita et al. 2011). Burkholderia pseudomallei was found to be unevenly distributed in soil and that the physicochemical properties of soil may partially influence the presence and absence of the bacterium (Ngamsang et al. 2015; Palasatien et al. 2008). Some microbes in soil may also inhibit or compete by producing some active compounds against the bacteria.

In this study, it was therefore of interest to screen for Bacillus spp. in soils that were negative for B. pseudomal$l e i$ and characterize the metabolites that could inhibit or kill B. pseudomallei. The Bacillus spp. themselves or their antimicrobial metabolites might then be used as bio-controls to prevent and reduce the incidence of melioidosis in endemic areas.

\section{Materials and methods}

\section{Bacterial strains}

Bacterial strains used to test for the inhibition spectrum of B. amyloliquefaciens metabolites are listed in Additional file 1: Table S1. They were obtained from the Melioidosis Research Center, Faculty of Medicine Khon Kaen University, Thailand and also kindly provided by Associate Professor Julian G. Hurdle's laboratory, Center for Infectious and Inflammatory diseases, Institute of Biosciences and Technology, Texas A\&M University, USA. Our bacterial strains were deposited in culture collection belonging to World Data Centre for Microorganism (WDCM) as MRCKKU (registration number 1130).

\section{Isolation of Bacillus spp. from soil}

Twenty-five soil samples that were confirmed as negative for B. pseudomallei by culture and semi-nested PCR (Ngamsang et al. 2015) were used for isolation of Bacillus spp.

The protocol for isolation of Bacillus spp. from soil was according to Travers et al. (1987) described with some modifications. One gram of each soil sample was mixed with $10 \mathrm{ml}$ sterile distilled water and boiled at $100{ }^{\circ} \mathrm{C}$ for $5 \mathrm{~min}$ to kill other vegetative cells. Thereafter, supernatants were diluted by 10 -fold serial dilution and $100 \mu \mathrm{l}$ of the $10^{-2}, 10^{-3}, 10^{-4}$ dilutions were spread onto nutrient agar (NA) plates and incubated at $37^{\circ} \mathrm{C}$ for $18-24 \mathrm{~h}$. Bacterial isolates with colony morphology of large, dry, white color with wavy, lobed margins were selected to subculture and confirmed by the Gram's stain. These isolates were tested for their ability to kill B. pseudomallei and other pathogens.

\section{Agar well diffusion method for screening of antimicrobial activity}

Antimicrobial activity against B. pseudomallei or other pathogens of culture supernatants and precipitated protein from culture supernatants of Bacillus spp. were investigated by the agar well diffusion method (Umer et al. 2013). In brief, overnight $1 \%$ cultures in Luria Bertani (LB) medium of $B$. pseudomallei and other indicator bacteria were inoculated into fresh LB medium and incubated at $37^{\circ} \mathrm{C}, 200 \mathrm{rpm}$ for $4 \mathrm{~h}$ until the log phase and were then used at approximately $10^{5}-10^{6} \mathrm{CFU} / \mathrm{ml}$ to swab on Müller-Hinton agar (MHA) plates. The plates were punched to obtain $6.6 \mathrm{~mm}$ wells by sterile pipette tips and then $100 \mu \mathrm{l}$ of sterile supernatant or precipitated proteins were added into each well. Ceftazidime (SigmaAldrich, St. Loius, MO, USA) at $50 \mu \mathrm{g} / \mathrm{ml}$ concentration was used as the positive control and minimal medium was used as the negative control. The plates were left at room temperature for $1 \mathrm{~h}$ before being incubated at $37{ }^{\circ} \mathrm{C}$, for $18-24 \mathrm{~h}$. Inhibition activity was evaluated by measuring the diameter of inhibition zone against $B$. pseudomallei.

\section{Species identification}

N2-4 and N3-8 with inhibitory activity against B. pseudomallei were selected for gDNA extraction with an RBC kit ( $\mathrm{RBC}$ ribosicen, Taiwan) and were then used for PCR amplification using universal primers against the conserved region in $16 \mathrm{~s}$ rDNA gene (Rd1; 5'AAGGAGGT GATCCAGCC3', Fd1; 5'AGTTTGATCCTGGCTCAG3') (Ghribi et al. 2012). The master mix of PCR contained $2.5 \mu \mathrm{l}$ of 10X PCR buffer, $0.16 \mathrm{mM}$ dNTP, $2.0 \mathrm{mM} \mathrm{MgCl}_{2}$, $0.1 \mu \mathrm{M}$ of each primer, $0.04 \mathrm{unit} / \mathrm{ml}$ of Taq DNA polymerase, $50 \mathrm{ng}$ of DNA template and DNase-free water to a final volume of $25 \mu \mathrm{l}$. The PCR products were analyzed with $1.2 \%$ agarose gel electrophoresis and stained with SYRB Gold. The expected PCR products of $1500 \mathrm{bps}$ were sequenced (First Base laboratories Sdn Bhd, Malaysia) and the BLASTn program was used (Altschul et al. 1997; National Center for Biotechnology Information 2015) to identify their species.

\section{Production kinetics of antimicrobial metabolites}

N2-4 and N3-8 were cultured in duplicate in $200 \mathrm{ml}$ of minimal medium composed of $5.0 \mathrm{~g}$ L-glutamic acid, $0.5 \mathrm{~g} \mathrm{KH}_{2} \mathrm{PO}_{4}, 0.5 \mathrm{~g} \mathrm{~K}_{2} \mathrm{HPO}_{4}, 0.2 \mathrm{~g} \mathrm{MgSO}_{4} \cdot 7 \mathrm{H}_{2} \mathrm{O}$, 
$0.01 \mathrm{~g} \mathrm{MnSO}_{4} \cdot \mathrm{H}_{2} \mathrm{O}, \mathrm{NaCl} 0.01 \mathrm{~g}, \mathrm{FeSO}_{4} \cdot 7 \mathrm{H}_{2} \mathrm{O} 0.01 \mathrm{~g}$, $\mathrm{CuSO}_{4} \cdot 7 \mathrm{H}_{2} \mathrm{O} 0.01 \mathrm{~g}$ and $\mathrm{CaCl}_{2} \cdot 2 \mathrm{H}_{2} \mathrm{O} 0.015 \mathrm{~g} / \mathrm{L}$. This was supplemented with $1 \% \mathrm{w} / \mathrm{v}$ sterile glucose as described by Jamil et al. (2007) at $37{ }^{\circ} \mathrm{C}$ with $200 \mathrm{rpm}$ shaking for $102 \mathrm{~h}$. Every $6 \mathrm{~h}, 1 \mathrm{ml}$ of the culture was sampled to obtain the culture supernatant for antimicrobial activity to test against B. pseudomallei using the agar well diffusion method.

\section{Partial characterization of antimicrobial metabolites from N2-4 and N3-8 \\ Proteolytic enzymes susceptibility test}

The culture supernatants from N2-4 and N3-8 were treated with $200 \mu \mathrm{g} / \mathrm{ml}$ of proteinase K (Amresco, Solon, $\mathrm{OH}$, USA) and $1 \mathrm{mg} / \mathrm{ml}$ of pepsin, trypsin and papain (Sigma-Aldrich, St. Loius, MO, USA) at final concentrations and incubated at $37^{\circ} \mathrm{C}$ for $3 \mathrm{~h}$. For inactivation, the proteinase $\mathrm{K}$ was processed at $75^{\circ} \mathrm{C}$ for $10 \mathrm{~min}$ or $100{ }^{\circ} \mathrm{C}$ for $5 \mathrm{~min}$ for the other three enzymes to determine the antimicrobial activity against $B$. pseudomallei by the agar wells diffusion method.

\section{Thermo stability test}

The culture supernatants from N2-4 and N3-8 were incubated at $25,37,40,50,60,70,80,90,100$, and $121{ }^{\circ} \mathrm{C}$ for $15 \mathrm{~min}$ and then tested for the antimicrobial activity against $B$. pseudomallei by the agar well diffusion method.

\section{Antimicrobial spectrum}

For a quick screening of the antimicrobial activity, the cross steak method was used as described by Hemashenpagam with some modifications (Hemashenpagam 2011). N2-4 or N3-8 isolates were streaked as a line at the center of the NA plate and incubated for $72 \mathrm{~h}$. After that, the overnight culture of indicator bacteria (Additional file 1: Table S1) was streaked across the single streak of N2-4 and N3-8 isolates and incubated at $37{ }^{\circ} \mathrm{C}$ for $24 \mathrm{~h}$. The qualitative grading of inhibition assigned ++++ for the highest, +++ for moderate, ++ for a few, + for low activity and - for no inhibition.

\section{Production of proteins from N2-4 and N3-8}

The production medium of secondary metabolites is a minimal medium supplemented with $1 \% \mathrm{w} / \mathrm{v}$ glucose sterile with a filtered $0.2 \mu \mathrm{m}$ syringe (Jamil et al. 2007). One percent of both B. amyloliquefaciens N2-4 and N3-8 were inoculated into minimal media and kept at $37{ }^{\circ} \mathrm{C}$, $200 \mathrm{rpm}$ for $72 \mathrm{~h}$. The cultured supernatants were harvested by centrifugation at $16,000 \times g$ for $15 \mathrm{~min}$, (Avanti ${ }^{\circledR}$ J-E, Beckman Coulter, CA, USA) and then filtered through a $0.2 \mu \mathrm{m}$ membrane. These crude metabolites were used for protein purification or kept at $-20{ }^{\circ} \mathrm{C}$ until used for the inhibition assay.

\section{Partial purification of proteins}

Culture supernatants from N2-4 and N3-8 were precipitated using 20, 40, 60 and 80\% saturated ammonium sulfate $\left(\left(\mathrm{NH}_{4}\right)_{2} \mathrm{SO}_{4}\right)$ as described by Sharma with some modification (Sharma et al. 2009). The precipitated proteins were harvested by centrifugation at $13,000 \times g$ (Avanti ${ }^{\circledR} \mathrm{J}-\mathrm{E}$, Beckman Coulter, CA, USA) at $4{ }^{\circ} \mathrm{C}$ for $20 \mathrm{~min}$. The protein pellets were then re-suspended in TE buffer $\mathrm{pH} 8.0$ (10 mM Tris- $\mathrm{HCl}, 1 \mathrm{mM}$ EDTA) and dialyzed with similar buffers using a dialysis bag with a $3.5 \mathrm{kDa}$ cut off (Thermo scientific, Rockford, IL, USA) at $4{ }^{\circ} \mathrm{C}$ overnight. The activity of these precipitated proteins was confirmed against B. pseudomallei and other pathogenic bacteria by the agar well diffusion method. The concentrations of the precipitated proteins were measured by the Bradford technique (Biorad, CA, USA) according to the manufacturers' protocol.

The precipitated proteins were prepared to have a concentration of $3.0 \mathrm{mg} / \mathrm{ml}$ and were tested for antimicrobial activity against 14 pathogenic bacteria by the agar well diffusion method as listed in the Additional file 1: Table S1.

\section{Time-kill assay of the precipitated proteins}

The time-kill assay, as described by Sopirala et al. (2010), with some modifications, was used to determine the time that B. pseudomallei was killed after N2-4 and N3-8 precipitated proteins were added into the $B$. pseudomallei cultures. Briefly, $3.0 \mathrm{mg} / \mathrm{ml}$ of precipitated proteins were twofold serial diluted with MHB in 24-well plates and then added $10^{5}-10^{6} \mathrm{CFU} / \mathrm{ml}$ of $B$. pseudomalle $i$ and incubated at $37{ }^{\circ} \mathrm{C}$. After incubation for 3, 6, 12 and $24 \mathrm{~h}$, $100 \mu \mathrm{l}$ from each dilution was 10 -fold serially diluted with PBS pH 7.2 and $10 \mu \mathrm{l}$ of each dilution were used to drop on selective Ashdown's agar (Naghili et al. 2013) for B. pseudomallei colony counts.

\section{Minimum inhibitory concentration (MIC) and Minimum bactericidal concentration (MBC) of antimicrobial compounds}

The precipitated proteins from N2-4 and N3-8 isolates were filtered through $0.2 \mu \mathrm{m}$ membranes and the concentrations adjusted to $3.0 \mathrm{mg} / \mathrm{ml}$ and used to determine the MIC and MBC by micro-broth dilution (Hoelzer et al. 2011). In brief, the antimicrobial compounds were diluted in 96-well plates by twofold serial dilutions using MHB. Then $B$. pseudomallei of approximately $10^{5}-10^{6}$ $\mathrm{CFU} / \mathrm{ml}$ was added into each well, mixed gently and then incubated at $37{ }^{\circ} \mathrm{C}$ for $18-24 \mathrm{~h}$. The last concentration that provided clear solution when compared to the growth control was recorded as the MIC. The MBC was evaluated by pipette each dilution from the clear wells, diluting with PBS pH 7.2 and then $10 \mu \mathrm{l}$ of each dilution 
was dropped onto Ashdown's agar for colony counts. The interpretation was that the MBC must have decreased $\geq 3$ $\log _{10} \mathrm{CFU} / \mathrm{ml}$ or $99.9 \%$ of the bacterial cell count when compared to growth control.

\section{Identification of proteins with antimicrobial activity}

The precipitated proteins were separated by native-PAGE in the tris-glycine system and the separated bands were used to test for the inhibitory activity as described by Barbaza-Corana (2007) with some modifications. Precipitated proteins were separated in duplicate; one strip was washed with sterile deionized water and placed on the MHA plate that was spread with $10^{5}-10^{6} \mathrm{CFU} / \mathrm{ml}$ B. pseudomallei, the strip without proteins loading was used as negative control. The inhibition zone against $B$. pseudomallei that was caused by proteins was observed after incubation at $37{ }^{\circ} \mathrm{C}$ for $18-24 \mathrm{~h}$. Another strip of this gel was stained with silver stain (Schägger 2006) to determine the molecular weight of the protein band that showed inhibition activity.

\section{Bio-control of B. pseudomallei using B. amyloliquefaciens}

B. pseudomallei at $6 \times 10^{6} \mathrm{CFU} / \mathrm{ml}$ were co-cultured with $6 \times 10^{4} \mathrm{CFU} / \mathrm{ml}$ of N2-4 or N3-8 isolates in $100 \mathrm{ml}$ of LB medium in $250 \mathrm{ml}$ Erlenmeyer flasks and incubated at $37^{\circ} \mathrm{C}$ with $200 \mathrm{rpm}$ shaking. The experiment was done in triplicate. Burkholderia pseudomallei cultured in the same condition was used as a control. The viability of $B$. pseudomallei was measured after co-culture for 24, 48, 72 and $96 \mathrm{~h}$ using the plate count method on Ashdown's agar.

\section{Results}

\section{Bacterial isolation and species identification}

Sixty-six isolates of Gram-positive bacilli, with morphology of being large, dry, white colored, with wavy, lobed margins were obtained. After the antimicrobial activity against $B$. pseudomallei was observed by the agar well diffusion method, the two isolates named N2-4 and N3-8 showed clear zones of inhibition (Fig. 1). PCR amplification against the conserved regions in 16s rDNA genes of N2-4 and N3-8 gave the expected 1500 bps products. The nucleotide sequences shown by BLASTn indicated $99 \%$ similarity to B. amyloliquefaciens. The accession numbers of $16 \mathrm{~s}$ rDNA that were identical to $16 \mathrm{~s}$ rDNA of N2-4 and N3-8 are KC887505.1 and HG32825.1.

\section{Production time of antimicrobial metabolites}

The metabolites from B. amyloliquefaciens N3-8 showed more broadened antimicrobial activity against $B$. pseudomallei and was therefore selected to grow in minimum medium in duplicate to observe the production of antimicrobial metabolites in time by the agar well diffusion

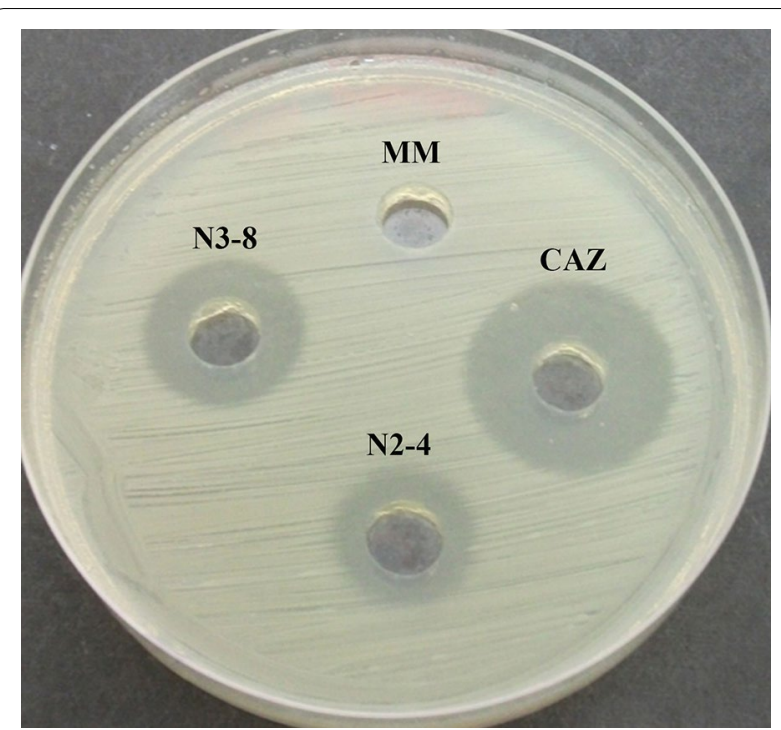

Fig. 1 The antimicrobial activity of culture supernatants from $B$. amyloliquefaciens N2-4 and N3-8 isolates against B. pseudomallei. The inhibitory activity of culture supernatants from $B$. amyloliquefaciens N2-4 and N3-8 isolates against B. pseudomallei by the agar well diffusion method as seen by clear zones, $M M$ minimal medium (negative control), CAZ ceftazidime $50 \mu \mathrm{g} / \mathrm{mL}$, the drug of choice for B. pseudomallei (positive control)

method. After being cultured for 12 and $14 \mathrm{~h}$, the culture supernatants from N3-8 and N2-4 started to show inhibition against $B$. pseudomallei. The highest antimicrobial activity was observed at $60-72 \mathrm{~h}$ with the inhibition zone of 20 and $17 \mathrm{~mm}$ (Fig. 2).

\section{Partial characterization of antimicrobial metabolites from B. amyloliquefaciens Proteolytic digestion and temperature stability}

When the culture supernatants from N3-8 were heated from $25^{\circ} \mathrm{C}$ to $121{ }^{\circ} \mathrm{C}$ for $15 \mathrm{~min}$, the activity against $B$. pseudomallei decreased at $40-100{ }^{\circ} \mathrm{C}$ and was almost halved when autoclaved at $121{ }^{\circ} \mathrm{C}$ while metabolites from N2-4 showed decreased in activity after heating at $80-100{ }^{\circ} \mathrm{C}$ and were abolished by being autoclaved (Additional file 1: Table S2). The activities of the culture supernatants from N3-8 were partially decreased when treated with all proteolytic enzymes while those of N2-4 were abolished by proteinase $\mathrm{K}$ and trypsin and partially decreased by papain and pepsin digestion (Additional file 1: Table S3).

\section{Antimicrobial spectrum of N2-4 and N3-8}

The culture supernatants from N3-8 inhibited $100 \%$ of B. pseudomallei clinically sourced strains, $83 \%$ of environmentally sourced strains, $100 \%$ ceftazidime resistant and $100 \%$ in mutant isolates while N2-4 inhibited these 


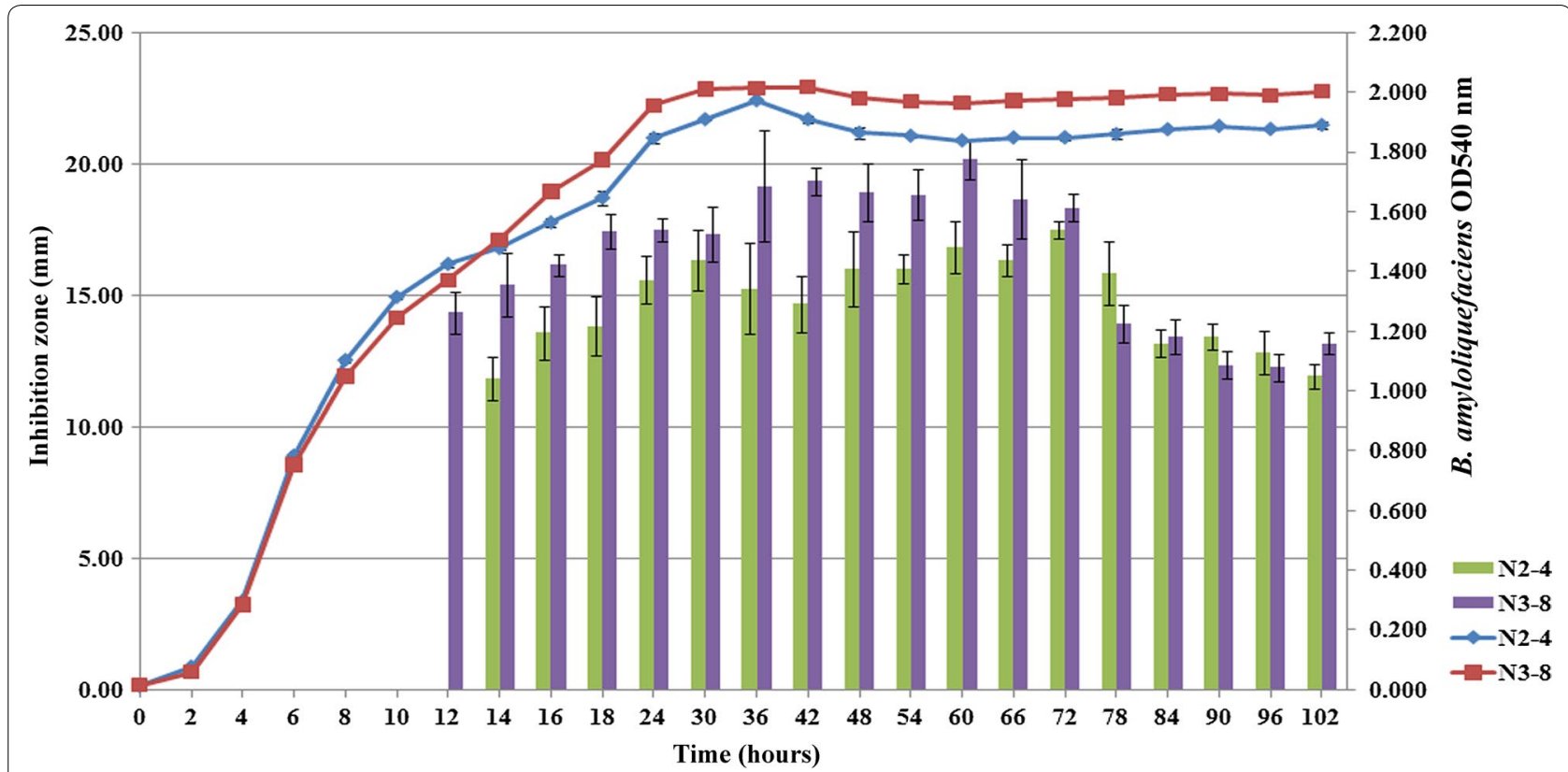

Fig. 2 The production of secondary metabolites from B. amyloliquefaciens N2-4 and N3-8 isolates. The production of secondary metabolites displayed as sizes of the inhibition zones in nm against B. pseudomallei as evaluated by the agar well diffusion method from N2-4 (green bars) and N3-8 (purple bars) were plotted on the left $Y$ axis and growth curve as measured at OD540 nm of N2-4 (blue line) and N3-8 (red line) were plotted on the right $Y$ axis, while $X$ axis represent the time in hours

same strains at $87,67,80$ and $60 \%$ (Table 1). They did not inhibit all 12 isolates of $B$. thailandensis, a non-pathogenic bacterium that is closely related to $B$. pseudomallei. Using the cross streak method, N2-4 and N3-8 isolates had clear inhibition activity against Gram-positive bacteria such as S. aureus, Clostridium difficile and Enterococcus faecium and other Gram-negative bacteria such as B. pseudomallei, Acinetobacter baumannii, Pseudomonas aeruginosa and E. coli (Additional file 1: Table S4).

\section{Partial purification and antimicrobial activity of precipitated proteins}

Sixty percent of saturated ammonium sulfate gave the precipitated proteins from the culture supernatants of N2-4 and N3-8 with the highest inhibition activity against B. pseudomallei. When these precipitated proteins from N2-4 and N3-8 were tested against Gram-positive and Gram-negative bacteria, they effectively inhibited S. pyogenes, S. pneumonia and Moraxella catarrhalis as shown with very large clear zones of inhibition (Table 2). Precipitated proteins from N3-8, in general, showed larger clear zones than N2-4.

The MICs of precipitated proteins from N2-4 and N3-8 were 0.19 and $0.02 \mathrm{mg} / \mathrm{ml}$. For MBCs, the concentrations of precipitated proteins from N2-4 and N3-8 that decreased B. pseudomallei colony counts by $99 \%$ were 0.75 and $0.04 \mathrm{mg} / \mathrm{ml}$.

\section{Time-kill assay of precipitated proteins}

The results from $\mathrm{MBC}$ assay confirmed that precipitated proteins from N2-4 and N3-8 could kill B. pseudomallei. The N2-4 precipitated proteins at concentrations of 3.0, 1.5 and $0.75 \mathrm{mg} / \mathrm{ml}$ could kill B. pseudomallei within 3,6 and $12 \mathrm{~h}$ (Fig. 3a). N3-8 proteins of $3.0 \mathrm{mg} / \mathrm{ml}$ could kill B. pseudomallei within $3 \mathrm{~h}$ and $0.09-1.5 \mathrm{mg} / \mathrm{ml}$ killed $B$. pseudomallei in $6 \mathrm{~h}$ and $0.04 \mathrm{mg} / \mathrm{ml}$ killed B. pseudomallei after being treated for $12 \mathrm{~h}$ (Fig. 3b). Therefore, the killing activity of these active compounds was in a dose dependent manner.

\section{Identification of proteins with antimicrobial activity}

Following the results of the in-gel overlay assay, the major active compounds that shown inhibitory activity against B. pseudomallei appeared at the lower end of the gel at the approximate molecular weight of less than $11 \mathrm{kDa}$ as shown by silver stained gel (Fig. $4 \mathrm{a}, \mathrm{b}$ ). The active compounds could be small molecules as separate bands on the silver stain gel.

\section{Bio-control of B. pseudomallei in liquid medium}

N2-4 and N3-8 were co-cultured with $6.0 \times 10^{6} \mathrm{CFU} /$ $\mathrm{ml}$ of B. pseudomallei at a ratio of 1:100 in LB broth. The growth rate of $B$. pseudomallei appeared to be decreased by $5 \log _{10}$ at $72 \mathrm{~h}$ after incubation when compared to the control growth (Fig. 5). 
Table 1 The antimicrobial activity of culture supernatant from B. amyloliquefaciens N2-4 and N3-8 isolates against $B$. pseudomallei and $B$. thailandensis

\begin{tabular}{|c|c|c|}
\hline Bacterial indicators & $\begin{array}{l}\text { B. amyloliquefaciens } \\
\text { N2-4 supernatants }\end{array}$ & $\begin{array}{l}\text { B. amyloliquefaciens } \\
\text { N 3-8 supernatants }\end{array}$ \\
\hline $\begin{array}{l}\text { B. pseudomallei clinical } \\
\text { isolates (16) }\end{array}$ & 14 & 16 \\
\hline $\begin{array}{l}\text { B. pseudomallei envi- } \\
\text { ronmental isolates } \\
\text { (6) }\end{array}$ & 4 & 5 \\
\hline $\begin{array}{l}\text { B. pseudomallei CAZ } \\
\text { resistance strains (5) }\end{array}$ & 4 & 5 \\
\hline $\begin{array}{l}\text { B. pseudomallei mutant } \\
\text { strains (5) }\end{array}$ & 3 & 5 \\
\hline M6 biofilm mutant & - & + \\
\hline M10 biofilm mutant & + & + \\
\hline $\begin{array}{l}\text { SRM117 LPS O-side } \\
\text { chain mutant }\end{array}$ & - & + \\
\hline $\begin{array}{l}\text { MM35 flagellin } \\
\text { mutant }\end{array}$ & + & + \\
\hline $\begin{array}{l}\text { SR1015 capsule } \\
\text { mutant }\end{array}$ & + & + \\
\hline B. thailandensis (12) & 0 & 0 \\
\hline
\end{tabular}

No. in brackets indicated number of test isolates

- Not inhibited, + inhibited

\section{Discussion}

Bacillus amyloliquefaciens was reported to be a plant promoting bacterium that was associated with rhizospheres as they consume nutrients from the plant. Moreover, this group of bacteria could produce secondary metabolites to suppress plant pathogens and also produce compounds to promote plant growth (Idris et al. 2007). The completed genome of $3918 \mathrm{~Kb}$ of the FZB42 strain showed a total of $8.5 \%$ of genetic material to be associated with the synthesis function of the non-ribosomal secondary metabolites (Chen et al. 2007) and 3693 sequences encoded for proteins. B. amyloliquefaciens FZB42 produces several non-ribosomal peptide products such as lipopeptides; surfactin, fengycin, and bacillomycin D (Koumoutsi et al. 2004) that can inhibit Fusarium oxysporum and polyketides; bacillaene, difficidin and macrolactin that also inhibited $F$. oxysporum (Chen et al. 2006; Schneider et al. 2007). Moreover, the peptides plantazolicin A, B and cyclic peptides amylocyclicin produced from this bacterium were also reported to inhibit $B$. subtilis and other closely related bacteria (Kalyon et al. 2011; Scholz et al. 2014). Bacilysin a dipeptide product from B. amyloliquefaciens FZB42 was able to suppress growth of E. amylovora which is the causative agent of fire blight disease (Chen et al. 2009). In this current study, B. amyloliquefaciens N2-4 and N3-8 that were isolated from soil, negative for $B$. pseudomallei, could inhibit $B$. pseudomallei and a wide range of human pathogens.
Table 2 The antimicrobial activity of precipitated proteins from B. amyloliquefaciens N2-4 and N3-8 against pathogenic bacteria

\begin{tabular}{|c|c|c|}
\hline \multirow[t]{2}{*}{ Bacterial indicators } & \multicolumn{2}{|c|}{ Inhibition zone ( $\varnothing \mathrm{mm})$} \\
\hline & $\begin{array}{l}\text { B. amyloliquefaciens } \\
\text { N2-4 proteins }\end{array}$ & $\begin{array}{l}\text { B. amyloliquefaciens } \\
\text { N3-8 proteins }\end{array}$ \\
\hline \multicolumn{3}{|c|}{ Gram-positive pathogenic bacteria } \\
\hline $\begin{array}{l}\text { Corynebacterium } \\
\text { diphtheriae }\end{array}$ & 17 & 23 \\
\hline $\begin{array}{l}\text { Streptococcus pneu- } \\
\text { moniae }\end{array}$ & $>30$ & $>30$ \\
\hline $\begin{array}{l}\text { Streptococcus pyo- } \\
\text { genes }\end{array}$ & 27 & 27 \\
\hline \multicolumn{3}{|c|}{ Gram-negative pathogenic bacteria } \\
\hline B. pseudomallei p37 & 21 & 24 \\
\hline Moraxella catarrhalis & $>30$ & $>30$ \\
\hline Citrobacter freundii & 14 & 18.5 \\
\hline Salmonella group D & 14.5 & 23 \\
\hline Proteus vulgaris & 14.5 & 23 \\
\hline Escherichia coli & 11 & 19.5 \\
\hline Shigella group D & 18 & 24 \\
\hline $\begin{array}{l}\text { Klebsiella pneumo- } \\
\text { niae }\end{array}$ & 11.5 & 15.5 \\
\hline $\begin{array}{l}\text { Acinetobacter bau- } \\
\text { mannii }\end{array}$ & 17.6 & 23 \\
\hline $\begin{array}{l}\text { Vibrio parahaemo- } \\
\text { lyticus }\end{array}$ & 0 & 15 \\
\hline $\begin{array}{l}\text { Stenotrophomonas } \\
\text { maltophilia }\end{array}$ & 23.8 & 28 \\
\hline
\end{tabular}

The metabolites with antimicrobial activity secreted from B. amyloliquefaciens N2-4 and N3-8 isolates were produced at the early to mid-stationary phase (12-72 h) when cell density become increased and the activity decreased after $78 \mathrm{~h}$ of cultivation. This characteristic fits well to the secondary metabolites that can be induced by multifactor such as stress, starvation or environmental factors and also cell-to-cell communication or quorum sensing which use small peptides as inducer (Kleerebezem and Quadri 2001). Antimicrobial activity of compounds from Bacillus spp. from the Amazon river basin were also capable of producing compounds with antimicrobial activity at the exponential phase and reached their peak at the stationary phase (Motta et al. 2007). The antimicrobial activity of culture supernatant from N2-4 were decreased by heat, abolished when autoclaved and can be completely destroyed by proteolytic enzymes suggesting that the main active compounds against B. pseudomallei are proteins. For N3-8, the heat, autoclaving and proteolytic enzymes digestion could only partially decrease the activity. Therefore, the active compounds should compose of peptides that can be digested by proteolytic enzyme and other compounds that resist 

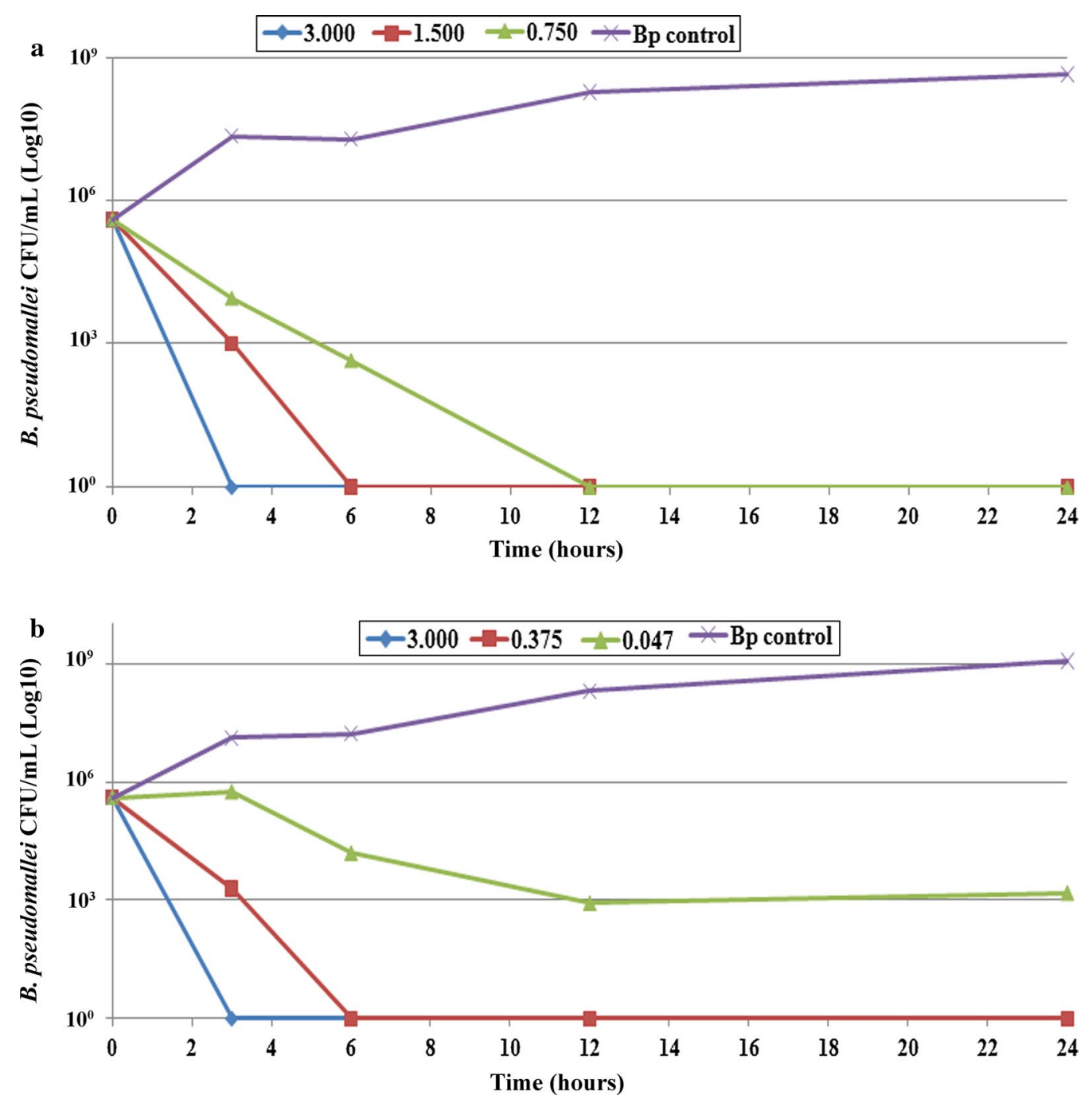

Fig. 3 Time-kill assay of precipitated proteins from B. amyloliquefaciens against B. pseudomallei. a Concentrations of precipitated proteins with the MBCs against B. pseudomallei from B. amyloliquefaciens N2-4 were used to lyse B. pseudomallei. The $X$ axis indicates time in hours after various concentrations of the proteins as indicated $(\mathrm{mg} / \mathrm{mL}$ ) were added into B. pseudomallei cultures and the $Y$ axis indicates the CFU/ml of B. pseudomallei after treatment. b Proteins from B. amyloliquefaciens N3-8 were tested in the same manner

to proteolytic enzyme and high temperature conditions. As mentioned, Bacillus spp. were reported to produce both peptides and non-ribosomal peptide antibiotics that can inhibit peptidoglycan synthesis or cause pore formation using some specific molecules such as lipid II or the mannose phosphate transferase system (man-PTS) as a docking molecule (Cotter et al. 2013). Lipopeptides are metabolites that can function as a pore formation or emulsification on the target organism. Several peptides and bacteriocin-like substances from Bacillus spp. were reported to stable at a wide range of temperatures $\left(30-80{ }^{\circ} \mathrm{C}\right.$ ) (Cao et al. 2011; Hammami et al. 2009; Sutyak et al. 2008). CLI proteins, for example, were stable up to
$60{ }^{\circ} \mathrm{C}$ and lost activity after being autoclaved at $121{ }^{\circ} \mathrm{C}$ (Meng et al. 2012) and a peptide subtilosin was stable after heat at $100{ }^{\circ} \mathrm{C}$ (Sutyak et al. 2008). The antimicrobial substances from B. amyloliquefaciens N2-4 and N3-8 were stable up to $25-100{ }^{\circ} \mathrm{C}$ and some activity was decreased when they were heated above $80{ }^{\circ} \mathrm{C}$. Moreover, the molecular weights of active fractions of precipitated proteins from both N2-4 and N3-8 were suspected to be less than $11 \mathrm{kDa}$. This information could indicate their metabolites to contain small peptides similar to bacteriocin antibiotics. Other compounds those were still active after proteolytic enzyme digestion could be the non-peptides group such as lipopeptides or polyketides. These 

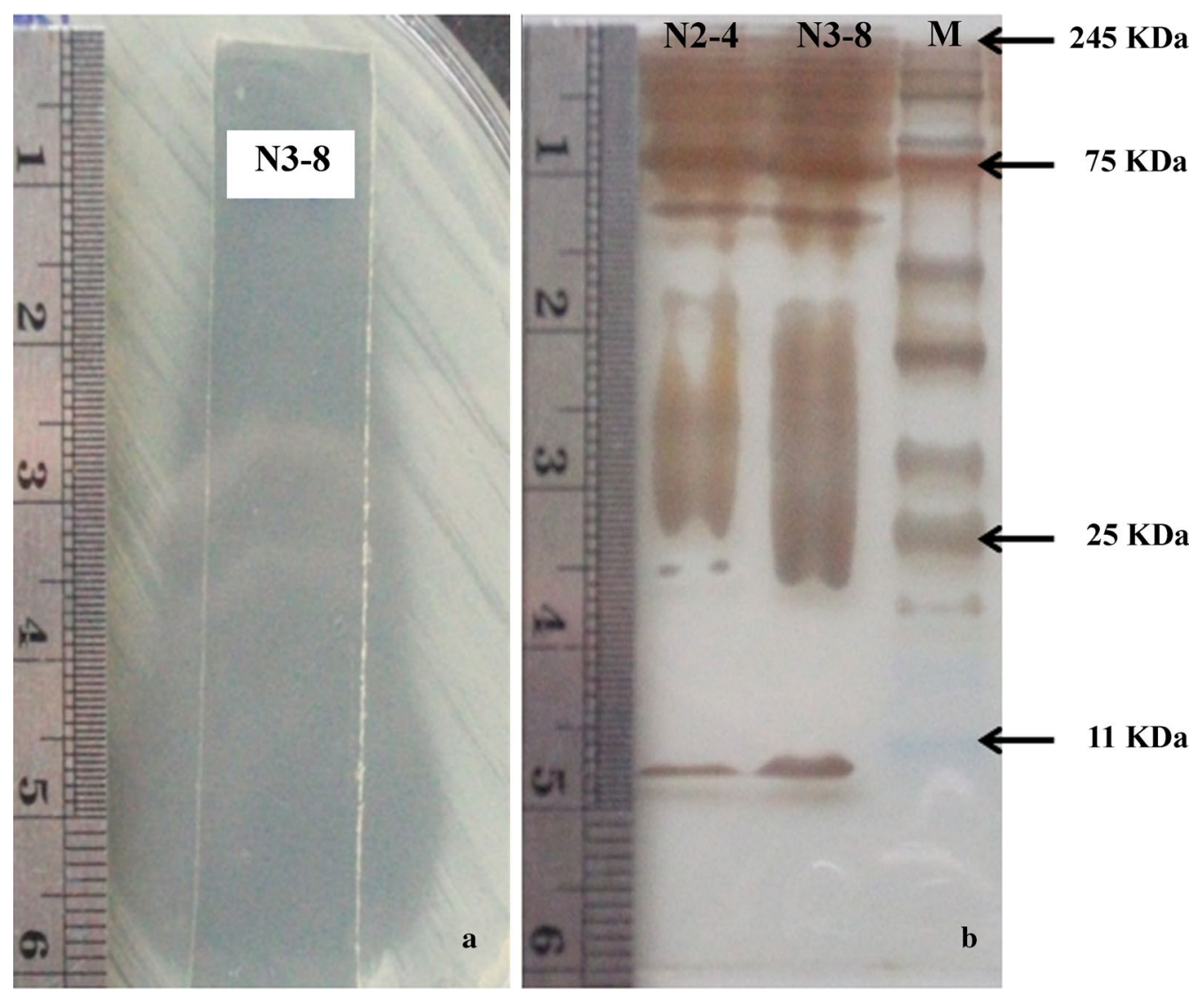

Fig. 4 Antimicrobial activity of precipitated proteins from B. amyloliquefaciens N2-4 and N3-8 isolates in native-PAGE against B. pseudomallei. a Clear inhibition zones of precipitated proteins from a strip of native-PAGE that was placed on the B. pseudomallei lawn. b Precipitated proteins from N2-4 and 3-8 were separated by native-PAGE and visualized by silver staining. $M$ represents the size marker

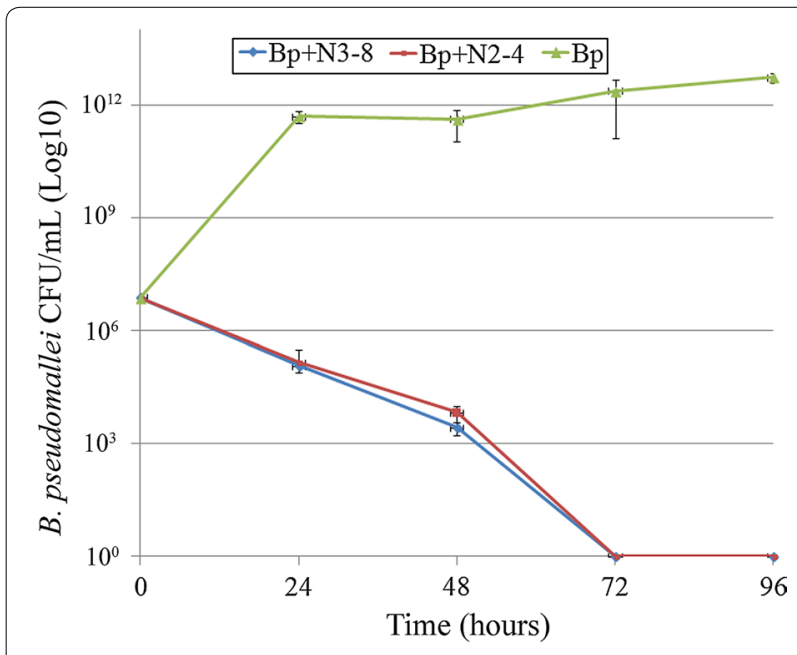

Fig. 5 Bio-control by co-culture B. pseudomallei with B. amyloliquefaciens. The colony count of $B$. pseudomallei was plotted on the $Y$ axis and time in hours on the $\mathrm{X}$ axis after co-culture with B. amyloliquefaciens isolates N2-4 (red line) and N3-8 (blue line) and the green line indicates the growth of un-treated B. pseudomallei as a control antimicrobial substances were reported to resist a wide range of temperatures up to $100{ }^{\circ} \mathrm{C}$ (Pathak and Keharia 2014) and were also resistant to proteolytic enzyme digestion (Zhao et al. 2013).

The active compounds produced from both $B$. amyloliquefaciens N2-4 and N3-8 isolates were able to inhibit several strains of $B$. pseudomallei from both clinical and environmental sources including antibiotic resistant isolates. Moreover, they could inhibit other Gram-positive and Gram-negative bacteria such as E. coli, S. aureus, E. faecium and C. difficile as shown by the cross-streak method. Surprisingly, these antimicrobial compounds did not inhibit $B$. thailandensis the non-pathogenic bacteria that is closely related to $B$. pseudomallei. The difference in lipopolysaccharide (LPS) structure between the $B$. pseudomallei and B. thailandensis have been reported (Knirel et al. 1992; Perry et al. 1995) together with the difference in their genomes (Brett et al. 1998) may contribute to the difference in their susceptibility to the antimicrobial compounds. Most of B. pseudomallei in Thailand have the 
LPS genotype A (Tuanyok et al. 2012) and K96243 and 1026b strains with genotype A were susceptible to N2-4 and N3-8 metabolites, however, the SRM117 LPS O-side chain mutant was susceptible to N3-8 but not N2-4. Moreover, M6 and M10, which are biofilm mutants, were more susceptible to N3-8 than N2-4. The nonpeptides compounds that are present in N3-8 but much less or none in the N2-4 as observed by heat and proteolytic stability test may be responsible for the differences when the culture supernatants were used to test for the spectrum of inhibition. Therefore, the precipitated proteins from N2-4 and N3-8 were prepared and tested with some pathogenic bacteria by agar well diffusion. Besides $S$. pyogenes and M. catarrhalis that showed equal inhibition, most of the test organisms were better inhibited by N3-8 than N2-4. Moreover, V. parahaemolyticus showed resistance to N2-4 but not N3-8. In general, most peptide antibiotics can inhibit bacteria in a narrow range or only closely related bacteria. Nevertheless, a bacteriocinlike substance of Bacillus spp. was reported to inhibit a broad-range of bacteria (Guo et al. 2012; Lee et al. 2001; Motta et al. 2007; Xie et al. 2009) that included B. amyoliquefaciens LBM5006 that inhibited L. monocytogenes, B. cereus, Serratia marcescens, E. coli, P. aeruginosa, P. fluorescens, S. cholerasuis, and S. gallinarum (Benitez et al. 2011). Similarly in this present study, the precipitated proteins from B. amyloliquefaciens N2-4 and N3-8 showed a broad range of inhibition. The metabolites of these two isolates should contain different compounds and the non-peptide metabolites in N3-8 may have a synergistic effect against these pathogens.

Several strains of B. amyloliquefaciens were studied to be used as bio-control agents such as the FZB42 strain that was dual-cultured with E. amylovora, both in vitro and in vivo, and showed inhibition activity in the growth of the pathogens (Chen et al. 2009). When B. amyloliquefaciens N2-4 and N3-8 were co-cultured with $B$. pseudomallei, they could decrease the growth of $B$. pseudomallei by $5 \log _{10}$ in $72 \mathrm{~h}$. The time of B. pseudomallei decrease was correlated with the time when the secondary metabolites from N2-4 and N3-8 were produced. Even though metabolites from N2-4 and N3-8 showed a broad spectrum of inhibition against both Gram-positive and Gram-negative pathogens, they did not affect B. thailandensis, a non-pathogenic bacterium from soil. Purification and characterization of both peptides and non-peptides from both isolates and the tests for their spectrum of inhibition may lead to a better knowledge to design a way for controlling B. pseudomallei in soil, and may also be extended to discover some important compounds to attack several problematic pathogens in the near future.
In conclusion, B. amyloliquefaciens N2-4 and N3-8 isolates obtained from soil can produce both peptides and non-peptide metabolites that can inhibit $B$. pseudomal$l e i$ and a broad range of other pathogenic bacteria. After purification and characterization, the bacteria themselves or their metabolites could be used as bio-controls to reduce the pathogenic bacteria in soil of endemic B. pseudomallei areas. Moreover, if the compounds are novel and safe, they may be good candidates for the development of new drugs.

\section{Additional file}

Additional file 1. Additional tables.

\section{Abbreviations}

LB: Luria-Bertani; CFU: colony forming unit; MIC: minimum inhibitory concentration; MBC: minimum bactericidal concentration; CAZ: ceftazidime; NativePAGE: native-polyacrylamide gel electrophoresis; EDTA: ethylenediamine tetrachloroacetic acid.

\section{Authors' contributions}

PB perform the majority of the experiments, CP identification of bacterial species, PB, CP and RWS designed the experiments, JGH antimicrobial spectrum analysis, PB and RWS drafted the manuscript. All authors read and approved the final manuscript.

\section{Author details \\ 1 Department of Biochemistry, Faculty of Medicine, Khon Kaen University, 123 Mitraparb Rd, Muang District, Khon Kaen Province 40002, Thailand. ${ }^{2}$ Melioido- sis Research Centre, Khon Kaen University, 123 Mitraparb Rd, Muang District, Khon Kaen Province 40002, Thailand. ${ }^{3}$ Center for Infectious and Inflamma- tory diseases, Institute of Biosciences and Technology, Texas A\&M University, 2121W. Holcombe Blvd, Houston, TX 77030, USA.}

\section{Acknowledgements}

We would like to thank Prof. James A. Will for editing the manuscript via Publication Clinic, Khon Kaen University, Thailand.

\section{Competing interests}

The authors declare that they have no competing interests.

\section{Availability of data and materials}

All data were included in the main manuscript and supplement files. List of the microorganism used in this manuscript was deposited in culture collection belonging to World Data Centre for Microorganism (WDCM) as MRCKKU (registration number 1130). The B. amyloliquefaciens N2-4 and N3-8 are available on collaboration.

\section{Ethics approval and consent to participate}

Not applicable since this article does not contain any studies with human participants or animals performed by any of the authors.

\section{Funding}

This work was supported by National Research Council of Thailand under the project of "New approaches for prevention of Melioidosis", the Higher Education Research Promotion and National Research University Project of Thailand, Office of the Higher Education Commission, through the heath cluster, project "Specific Health Problem in Greater Mekong Sub-region (SHeP-GMS)" of Khon Kaen University, Melioidosis Research Center, Khon Kaen University, Thailand.

Received: 25 September 2016 Accepted: 7 December 2016

Published online: 04 January 2017 


\section{References}

Altschul SF, Madden TL, Schaffer AA, Zhang J, Zhang Z, Miller W, Lipman DJ (1997) Gapped blast and Psi-blast: a new generation of protein database search programs. Nucleic Acids Res 25:3389-3402

Barboza-Corona JE, Vazquez-Acosta H, Bideshi DK, Salcedo-Hernandez R (2007) Bacteriocin-like inhibitor substances produced by Mexican strains of Bacillus Thuringiensis. Arch Microbiol 187:117-126

Benitez L, Correa A, Daroit D, Brandelli A (2011) Antimicrobial activity of Bacillus Amyloliquefaciens Lbm 5006 is enhanced in the presence of Escherichia Coli. Curr Microbiol 62:1017-1022

Brett PJ, DeShazer D, Woods DE (1998) Burkholderia Thailandensis sp. nov., a Burkholderia Pseudomallei-like species. Int J Syst Bacteriol 1:317-320

Cao H, He S, Wei R, Diong M, Lu L (2011) Bacillus Amyloliquefaciens G1: a potential antagonistic bacterium against eel-pathogenic Aeromonas Hydrophila. Evid Based Complement Alternat Med 824104:5

Chantratita N, Rholl DA, Sim B, Wuthiekanun V, Limmathurotsakul D, Amornchai P, Thanwisai A, Chua HH, Ooi WF, Holden MT, Day NP, Tan P, Schweizer HP, Peacock SJ (2011) Antimicrobial resistance to ceftazidime involving loss of penicillin-binding protein 3 in Burkholderia Pseudomallei. Proc Natl Acad Sci U S A 108:17165-17170

Chen XH, Vater J, Piel J, Franke P, Scholz R, Schneider K, Koumoutsi A, Hitzeroth G, Grammel N, Strittmatter AW, Gottschalk G, Sussmuth RD, Borriss R (2006) Structural and functional characterization of three polyketide synthase gene clusters in Bacillus Amyloliquefaciens Fzb42. J Bacteriol 188:4024-4036

Chen XH, Koumoutsi A, Scholz R, Eisenreich A, Schneider K, Heinemeyer I, Morgenstern B, Voss B, Hess WR, Reva O, Junge H, Voigt B, Jungblut PR, Vater J, Sussmuth R, Liesegang H, Strittmatter A, Gottschalk G, Borriss R (2007) Comparative analysis of the complete genome sequence of the plant growth-promoting bacterium Bacillus Amyloliquefaciens Fzb42. Nat Biotechnol 25:1007-1014

Chen XH, Scholz R, Borriss M, Junge H, Mogel G, Kunz S, Borriss R (2009) Difficidin and bacilysin produced by plant-associated Bacillus Amyloliquefaciens are efficient in controlling fire blight disease. J Biotechnol 140:38-44

Cheng AC, Currie BJ (2005) Melioidosis: epidemiology, pathophysiology, and management. Clin Microbiol Rev 18:383-416

Cotter PD, Ross RP, Hill C (2013) Bacteriocins - a viable alternative to antibiotics? Nat Rev Microbiol 11:95-105

Errington J (2003) Regulation of endospore formation in Bacillus Subtilis. Nat Rev Microbiol 1:117-126

Ghribi D, Abdelkefi-Mesrati L, Mnif I, Kammoun R, Ayadi I, Saadaoui I, Maktouf S, Chaabouni-Ellouze S (2012) Investigation of antimicrobial activity and statistical optimization of Bacillus Subtilis Spb1 biosurfactant production in solid-state fermentation. J Biomed Biotechnol 373682:24

Guo Y, Yu Z, Xie J, Zhang R (2012) Identification of a New Bacillus Licheniformis strain producing a bacteriocin-like substance. J Microbiol 50:452-458

Hammami I, Rhouma A, Jaouadi B, Rebai A, Nesme X (2009) Optimization and biochemical characterization of a bacteriocin from a newly isolated Bacillus Subtilis strain 14b for biocontrol of Agrobacterium spp. strains. Lett Appl Microbiol 48:253-260

Hemashenpagam N (2011) Purification of secondary metabolites from soil Actinomycetes. Int J Microbiol Res 3:148-156

Hoelzer K, Cummings KJ, Warnick LD, Schukken YH, Siler JD, Gröhn YT, Davis MA, Besser TE, Wiedmann M (2011) Agar disk diffusion and automated microbroth dilution produce similar antimicrobial susceptibility testing results for Salmonella serotypes newport, typhimurium, and 4,5,12:1-, but differ in economic cost. Foodborne Pathog Dis 8:1281-1288. doi:10.1089/ fpd.2011.0933

Huang T-P, Tzeng DD-S, Wong ACL, Chen C-H, Lu K-M, Lee Y-H, Huang W-D, Hwang B-F, Tzeng K-C (2012) DNA polymorphisms and biocontrol of Bacillus antagonistic to citrus bacterial canker with indication of the interference of phyllosphere biofilms. PLOS ONE 7:e42124. doi:10.1371/ journal.pone.0042124

Idris EE, Iglesias DJ, Talon M, Borriss R (2007) Tryptophan-dependent production of indole-3-acetic acid (laa) affects level of plant growth promotion by Bacillus Amyloliquefaciens Fzb42. Mol Plant Microbe Interact 20:619-626

Jamil B, Hasan F, Hameed A, Ahmed S (2007) Isolation of Bacillus Subtilis Mh-4 from soil and its potential of polypeptidic antibiotic production. Pak J Pharm Sci 20:26-31
Kalyon B, Helaly SE, Scholz R, Nachtigall J, Vater J, Borriss R, Sussmuth RD (2011) Plantazolicin a and B: structure elucidation of ribosomally synthesized thiazole/oxazole peptides from Bacillus Amyloliquefaciens Fzb42. Org Lett 13:2996-2999

Kleerebezem M, Quadri LE (2001) Peptide pheromone-dependent regulation of antimicrobial peptide production in gram-positive bacteria: a case of multicellular behavior. Peptides 22:1579-1596

Knirel YA, Paramonov NA, Shashkov AS, Kochetkov NK, Yarullin RG, Farber SM, Efremenko VI (1992) Structure of the Polysaccharide chains of Pseudomonas Pseudomallei lipopolysaccharides. Carbohydr Res 233:185-193

Koumoutsi A, Chen X-H, Henne A, Liesegang H, Hitzeroth G, Franke P, Vater J, Borriss R (2004) Structural and functional characterization of gene clusters directing nonribosomal synthesis of bioactive cyclic lipopeptides in Bacillus Amyloliquefaciens strain Fzb42. J Bacteriol 186:1084-1096. doi:10.1128/jb.186.4.1084-1096.2004

Lee KH, Jun KD, Kim WS, Paik HD (2001) Partial characterization of polyfermenticin scd, a newly identified bacteriocin of Bacillus Polyfermenticus. Lett Appl Microbiol 32:146-151

Meng QX, Jiang HH, Hanson LE, Hao JJ (2012) Characterizing a novel strain of Bacillus Amyloliquefaciens Bac03 for potential biological control application. J Appl Microbiol 113:1165-1175

Motta AS, Cannavan FS, Tsai SM, Brandelli A (2007) Characterization of a broad range antibacterial substance from a new Bacillus species isolated from amazon basin. Arch Microbiol 188:367-375

Naghili H, Tajik H, Mardani K, Razavi Rouhani SM, Ehsani A, Zare P (2013) Validation of drop plate technique for bacterial enumeration by parametric and nonparametric tests. Vet Res Forum 4:179-183

National Center for Biotechnology Information (2015) https://blast.ncbi.nlm. nih.gov/Blast.cgi. Accessed 1 Jul 2015

Ngamsang R, Potisap C, Boonmee A, Lawongsa P, Chaianunporn T, Wongratanacheewin S, Rodrigues JL, Sermswan RW (2015) The contribution of soil physicochemical properties to the presence and genetic diversity of Burkholderia Pseudomallei. Southeast Asian J Trop Med Public Health $46: 38-50$

Palasatien S, Lertsirivorakul R, Royros P, Wongratanacheewin S, Sermswan RW (2008) Soil physicochemical properties related to the presence of Burkholderia Pseudomallei. Trans R Soc Trop Med Hyg 102:70003-70008

Pathak KV, Keharia H (2014) Application of extracellular lipopeptide biosurfactant produced by endophytic Bacillus Subtilis K1 isolated from aerial roots of banyan (Ficus Benghalensis) in microbially enhanced oil recovery (Meor). 3. Biotech 4:41-48. doi:10.1007/s13205-013-0119-3

Perry MB, MacLean LL, Schollaardt T, Bryan LE, Ho M (1995) Structural Characterization of the lipopolysaccharide $O$ antigens of Burkholderia Pseudomallei. Infect Immun 63:3348-3352

Ramli NS, Eng Guan C, Nathan S, Vadivelu J (2012) The effect of environmental conditions on biofilm formation of Burkholderia Pseudomallei clinical isolates. PLOS ONE 7:6

Sansinenea E, Ortiz A (2011) Secondary metabolites of soil Bacillus spp. Biotechnol Lett 33:1523-1538

Schägger H (2006) Tricine-sds-page. Nat Proc 1:16-22

Schneider K, Chen XH, Vater J, Franke P, Nicholson G, Borriss R, Sussmuth RD (2007) Macrolactin is the polyketide biosynthesis product of the Pks2 cluster of Bacillus Amyloliquefaciens Fzb42. J Nat Prod 70:1417-1423

Scholz R, Vater J, Budiharjo A, Wang Z, He Y, Dietel K, Schwecke T, Herfort S, Lasch P, Borriss R (2014) Amylocyclicin, a novel circular bacteriocin produced by Bacillus Amyloliquefaciens Fzb42. J Bacteriol 196:1842-1852

Sharma N, Kapoor G, Gautam N, Neopaney B (2009) Characterization of a partially purified bacteriocin of Bacillus sp Mtcc 43 isolated from rhizosphere of radish (Raphanus Sativus) \& its application as a potential food biopreservative. J Sci Ind Res 68:881-886

Sopirala MM, Mangino JE, Gebreyes WA, Biller B, Bannerman T, Balada-Llasat JM, Pancholi P (2010) Synergy testing by etest, microdilution checkerboard, and time-kill methods for pan-drug-resistant Acinetobacter Baumannii. Antimicrob Agents Chemother 54:4678-4683

Sutyak KE, Wirawan RE, Aroutcheva AA, Chikindas ML (2008) Isolation of the Bacillus Subtilis antimicrobial peptide subtilosin from the dairy product-derived Bacillus Amyloliquefaciens. J Appl Microbiol 104:1067-1074

Travers RS, Martin PAW, Reichelderfer CF (1987) selective process for efficient isolation of soil Bacillus spp. Appl Environ Microbiol 53:1263-1266 
Tuanyok A, Stone JK, Mayo M, Kaestli M, Gruendike J, Georgia S, Warrington S, Mullins T, Allender CJ, Wagner DM, Chantratita N, Peacock SJ, Currie BJ,

Keim P (2012) The genetic and molecular basis of O-antigenic diversity in Burkholderia Pseudomallei lipopolysaccharide. PLoS Negl Trop Dis 6:e1453. doi:10.1371/journal.pntd.0001453

Umer S, Tekewe A, Kebede N (2013) Antidiarrhoeal and Antimicrobial activity of Calpurnia Aurea leaf extract. BMC Complement Altern Med 13:1472-6882

Wiersinga WJ, Currie BJ, Peacock SJ (2012) Melioidosis. N Engl J Med 367:1035-1044
Xie J, Zhang R, Shang C, Guo Y (2009) Isolation and characterization of a bacteriocin produced by an isolated Bacillus Subtilis Lfb112 that exhibits antimicrobial activity against domestic animal pathogens. Afr J Biotechnol 8:5611-5619

Zhao P, Quan C, Jin L, Wang L, Wang J, Fan S (2013) Effects of critical medium components on the production of antifungal lipopeptides from Bacillus Amyloliquefaciens Q-426 exhibiting excellent biosurfactant properties. World J Microbiol Biotechnol 29:401-409

\section{Submit your manuscript to a SpringerOpen ${ }^{\odot}$ journal and benefit from:}

- Convenient online submission

- Rigorous peer review

- Immediate publication on acceptance

- Open access: articles freely available online

- High visibility within the field

- Retaining the copyright to your article 